are presented in a simple form. The term crystallization or "crystallization in motion" is reserved for the supplementary stage of crystallization by cooling and mechanical stirring. Sulficient consideration is given to steam generation, designs of boilers commonly used, and steam efficiency. The technology of sugar refining is only very briefly treated, just enough to explain the importance of the refining qualities of raw sugar.

The practice of listing references at the end of each chapter leads to needless repetition and a considerable waste of space. The few typographical errors could have been eliminated by more careful proof-roading. This book shows a practical approach, is well balanced, amply illustrated, and pleasing in stylo. It can be recommended confidently.

D. Gross

\section{FRESH FISH}

Fish and Fish Inspection

By John D. Syme. Second edition. Pp. xi+211. (London: H. K. Lewis and Co., Ltd., 1966.) 42s. net.

THis substantial revision of the only work of its kind now treats such important industrial developments since 1949 as fish freezing at sea and mechanical fish smoking in addition to other aspects of fish handling at sea and port, including salt-curing, canning and fish meal. The author is port health inspector at Grimsby and the book is written in a practical fashion primarily for men preparing for examination as inspectors of meat and other foods of the Royal Society of Health. 'The fish side of food inspection is still very much neglected in comparison with meat, which has special health hazards, and this book presents much useful information for the purpose. There are only ten pages of precepts regarding actual methods of fish inspection, for which of course there is no substitute for practical experience. Three chapters cover fishing vessels, grounds and catching and handling at sea. There are fifty pages describing the external characteristics of the principal commercial species. Fish parasites and diseases and cleansing of shell fish are referred to briefly. A final chapter summarizes United Kingdom legislation on fish. The aspirant would do well to check the Latin nomenelature.

C. L. Cutring

\section{PESTS}

\section{Natural Pest Control Agents}

(A Symposium sponsored by the Pesticides Sub-division of the Division of Agricultural and Food Chemistry at the 149th Meeting of the American Chemical Society, Detroit, Mich., April 8, 1965. Advances in Chem. Series, No. 53.) Pp. vi +146 . (Washington, D.C.: American Chemical Society, 1966.) \$5.75.

THrs symposium comprises twelve brief but meaty contributions. The introductory paper explains that "natural pest control agents" are the complex chemicals secreted by organisms for defence or aggression. The next six papers deal with agents for controlling insects (attractants, repellents, toxins), and it is intriguing to learn, for example, that the edible parts of turnips contain 63 p.p.m. of a substance designated 2-phenylethylisothiocyanate which at 0.5 per cent $(\mathrm{w} / \mathrm{v})$ is more lethal to insects than 'Lethane 384'. Two other papers are concerned with agents for controlling plant diseases, namely antifungal substances and virus replication inhibitors present in various plants. Another two are devoted to agents for controlling plant processes from germination to senescence, with the question of producing selective herbicides well to the fore. Chemists may admire paper 11 as "a beautiful pieco of research on the isolation and structure proof of the toxin from Helminthosporium sativum" (a fungus of barley), but agriculturalists will certainly be interested in it as an indication of the possibility of "a structural type of systemic herbicide".

From various indirect remarks throughout the volume, it is clear that the late Miss Rachel Carson has stimulated a considerable effort in the United States to find "natural pest control chemicals". Since chemical pesticides are indispensable (at least for the present), such "natural chemicals" are preferable because they are less persistent. The danger, of course, is that the chemists will proceed to synthesize ultra-stable analogues which may be as undosirable as chlorinated hydrocarbons. Although chiefly for chemists, this book also contains much useful information for biologists engaged in pest control.

Alec Milne:

\section{ANIMAL HEALTH}

\section{Advances in Veterinary Science}

Vol. 10. Edited by C. A. Brandly and Charles Cornelius. Pp. xiii + 305. (New York: Academic Press, Inc.; London: Academic Press, Inc. (London), Ltd., 1965.) \$13.

'THE contents of this volume are somewhat heterogenoous. The opening chapter deals with intrauterine foetal surgery, the next four chapters with four animal disoases-. vesicular exanthema, Rift Valley fever, bovine enzootic: leucosis, and mycoplasmosis - whilo the last two chapter's are concerned with the application in modern veterinary practice of two groups of therapeutic agents, namely, sulphonamides and antibiotics.

Surgery porformed on a foetus in utero is gradually assuming an outstandingly significant role in studies of animal development, and for that reason the chapter on intrauterine foetal surgery will be read with much interest and appreciation by all investigators of the manifold aspocts of foetal physiology and pathology. Up to now, the foctal lamb seems to have had more than its fair share of interest from surgeons, but other species are beginning increasingly to receive attention. The day may not bo far off when intrauterine techniques will havo achieved a degree of perfection sufficient to attempt a surgical correction of foetal deformities.

Vesicular exanthema, once a dreaded disease of pigs, has now been practically vanquished. The key to eradication was surprisingly simple: compulsory cooking of garbage intended for pig feeding. Rift Valley fever, the acute arthropod-borne viral disease first studied systematically some thirty years ago in a sheep farm in the Rift Valley of Kenya, still constitutes a dangerous threat to livestock, particularly in Africa. If the long list of references attached to that chapter is in any way indicative of the research effort, then the eradication of RVF must surely be in sight. Bovine enzootic leucosis, which is probably also viral in nature, prefers Europe to Africa. The tumours which it produces in cattle, once variedly described as lymphosarcoma, lymphoblastoma or leukaemia, constitute the most common type of neoplasia in cattle. As no treatment exists at prosent for leucosis, total slaughter of the affected herds seems to represent the only practicable way of eliminating foci of the disease. Mycoplasmosis, referred to in the preface to the volume as "an insidious malady of multiple host spectrum . . . grudgingly yiolding to scientific attack", provides another example of a disoase which so far has resisted chemotherapy. Yet it is a particularly serious malady, in view of the possible role of mycoplasmas in heart disease.

The two concluding chapters, dealing with sulphonamides and antibiotics, carry the hope that eradication by slaughter may not be the sole means of protecting livestock from their manifold and serious infestations. Nevertheless, one would also wish to be assured that, treatment of the food-producing animals with the various potent therapeutic agents will not unduly endanger the human consumer. 